\title{
BRASIL: LIBERALISMO, CAFÉ, ESCOLA E VOTO (1878-1881)'
}

\section{Alceu Ravanello Ferraro*}

RESUMO: O trabalho mostra como, num país agrário, latifundiário e escravocrata, em pleno ciclo do café, com uma população predominantemente rural e absolutamente desprovida de escolas, as elites brasileiras, agora representadas maciçamente por liberais na Câmara dos Deputados, conseguem, por meio da Lei Saraiva (1881), unir, num casamento que duraria mais de um século, duas coisas aparentemente inconciliáveis na perspectiva liberal: de um lado, o voto direto; de outro, a exclusão da grande massa do povo, os analfabetos ( $80 \%$ da população), do direito de voto. O estudo mostra ainda quão diferente foi o caminho seguido pela vizinha Argentina, por meio da Lei de Educação Comum (1884). Conclui lembrando as palavras de José Bonifácio o Moço, para quem, com a exclusão dos analfabetos do direito de voto, o projeto liberal de eleição direta em discussão na Câmara não era a bandeira da reforma, mas sim a reforma da bandeira liberal.

Palavras-chave: Brasil; Liberalismo; Analfabetos; Voto; Memória Social.

\section{BRAZIL: LIBERALISM, COFFEE, SCHOOL AND VOTE (1878-1881)}

ABSTRACT: The paper shows how, in an agrarian country like Brazil, dominated by large land owners and slave holders, in the middle of the so-called coffee cycle, with a predominantly rural population that had absolutely no access to school education, the Brazilian elites, at that time massively represented by liberals at the Chamber of Deputies, managed to unite through the Saraiva Act (1881), in a partnership that lasted more than one century, two things apparently incompatible from a liberal perspective: the direct vote and the exclusion of the great mass of the people, viz, the illiterate $(80 \%$ of the population), from the right to vote. It also shows the different path adopted in Argentina through the Law of Common Education (1884). It concludes by recalling a statement by José Bonifácio, the Young: according to him, because of the exclusion of the illiterate from the right to vote, the liberal draft bill on direct election was not the banner of reform, but the reform of the [liberal] banner.

Keywords: Brazil; Liberalism; Illiteracy; Vote; Social Memory.

* * Doutor em Ciências Sociais pela Pontifícia Universidade Gregoriana, Roma, 1969; Professor Titular aposentado da Universidade Federal do Rio Grande do Sul e docente convidado do Programa de Pós-Graduação em Educação da mesma Universidade; Pesquisador do Conselho Nacional de Desenvolvimento Científico e Tecnológico (CNPq). E-mail: aferraro@adufrgs.ufrgs.br 
O título pode soar estranho, mas penso que ele introduz bem os elementos fundamentais das intricadas relações que pretendo examinar no presente trabalho. A atenção volta-se para o período dos ministérios liberais presididos por Casansão Sinimbu e Antônio Saraiva, nos anos de 1878 a 1882, a quem o Imperador confiava a tarefa de introduzir o voto direto, justamente no momento em que a Monarquia brasileira tomava o caminho de seu ocaso.

O café representava então o carro-chefe da economia - uma economia ainda essencialmente agrária e latifundiária, que, além disso, ou mais que isso, continuava recusando-se a abrir mão do trabalho escravo. Para a tarefa exclusiva de introduzir o voto direto, o Imperador chama o partido liberal, o qual tinha inscrito em sua bandeira esse objetivo, embora, ao que se saiba, não o de alargar a participação política. Ao arrocho no que se refere ao censo (à comprovação de renda) para poder votar, os liberais adicionam a exigência de saber ler e escrever, e isso num país quase sem escolas, em que mais de $80 \%$ das pessoas em idade de votar eram analfabetas. É a conjugação de todo esse conjunto de elementos que justifica reunir no título os termos liberalismo, café, escola e voto.

A explicitação da relação entre esses elementos pode ser feita a partir de duas perguntas. A primeira: Como, num país sem escolas, os liberais aceitaram a tarefa de introduzir a eleição direta ao preço de excluírem do direito de voto a população analfabeta, que, então, representava mais de $80 \%$ das pessoas adultas? A segunda: Podia o liberalismo, num país agrário-exportador, latifundiário e ainda teimosamente escravocrata, junto com a introdução do voto direto, alargar a participação popular no processo político?

\section{A questão eleitoral}

Os historiadores costumam datar do estelionato eleitoral de 1868 o início da crise eleitoral que veio a somar-se a todo um conjunto de crises - a militar, a religiosa, a escravista - que acabaria levando a Monarquia brasileira a seu término. Esse estelionato consubstanciava-se no fato de o Imperador haver imposto, nesse ano, a uma Câmara de maioria liberal, um gabinete ultraconservador chefiado pelo Visconde de Itaboraí. Como se lê na História Geral da Civilização Brasileira, "Itaboraí era o último grande 
chefe de tipo antigo do partido [conservador]. [...] Itaboraí é a grande presença do passado, quando um novo grupo de chefes está ascendendo e vai empolgar a direção conservadora no fim do Império". Foi "terrível" o impacto causado por "um ministério conservador quando a Câmara dos Deputados era de maioria progressista, agora liberal” (IGLESIAS. In: HOLANDA, 1982, p. 1009).

O Gabinete Itaboraí pôs fim a uma sequência de três breves ministérios liberais (1865/68) que o haviam precedido. A oposição negava-lhe representatividade, registrando com vigor o seu protesto contra o que chamava de "novo estelionato eleitoral", igual ao de 1848, quando, pela primeira vez, os conservadores haviam posto fim a um curto período de gabinetes liberais-relâmpago (agosto de 1847 a setembro de 1848), mantendo-se no poder por mais de uma década (1848 a 1862), seguidos da Liga Progressista (1862/1864). Ao gabinete conservador Itaboraí $(1868 / 70)$ seguem-se outros três gabinetes do mesmo partido, mas já de novo tipo, como se esclarecerá adiante.

Essa sequência de gabinetes conservadores só é interrompida em 1878, quando o Imperador, não podendo mais conter as vozes em favor da eleição direta, chama um liberal, escolhido a dedo, para formar um governo com a missão exclusiva de introduzir a eleição direta no país. Chega-se, assim, ao gabinete liberal de 5 de janeiro de 1878, presidido pelo Visconde João Lins Vieira Casansão de Sinimbu (1878/80), depois seguido pelo gabinete de 28 de março de 1880, presidido pelo também liberal Conselheiro José Antônio Saraiva (1880/1882), de grande prestígio no partido.

O Visconde de Sinimbu nasceu em Pernambuco em 20 de novembro de 1810, na fazenda Sinimbu, na região que se transformaria na província de Alagoas. Foi ministro em diversos gabinetes e presidente do Conselho de ministros, de 5 de janeiro de 1878 a 23 de março de 1880. No breve perfil biográfico que lhe traça Marco Aurélio Martins Santos, lê-se que

sua escolha, quebrando a hegemonia de 14 anos dos conservadores, desagradou a alguns liberais que viam no gesto apenas uma opção pessoal do Imperador e não um verdadeiro repasse de poder ao partido opositor. Por ocasião da reforma eleitoral, sua decisão de apresentar projeto excluindo o voto dos analfabetos causou divisão no partido, acarretando na ida de vários liberais para a oposição. Com isso, seu gabinete ficou enfraquecido e acabou demitido para que outro liberal - Saraiva - presidisse o ministério (SANTOS citado por SENRA, I, 2006, p. 412). 
Os debates sobre o projeto de reforma eleitoral do Ministério Sinimbu foram precedidos por intensas discussões provocadas pelo próprio teor da fala do trono na sessão de abertura da $17^{\text {a }}$ Legislatura, no Paço do Senado, em 15 de dezembro de 1878. Nessa sessão, o Imperador dirigira-se à Assembléia Geral em termos que suscitaram a ira de um grupo de liberais, que passaram a constituir a oposição liberal ao próprio governo liberal. Dissera então o Imperador:

Reconhecida a necessidade de substituir o sistema eleitoral vigente pelo de eleição direta, cumpre que decreteis mediante reforma constitucional, afim de que o concurso de cidadãos, devidamente habilitado a exercer tão importante direito, contribua eficazmente para realidade do sistema representativo (CÂMARA, Anais, 15/12/1878. Acesso em: 19 ago. 2007. É meu o grifo).

Dois pontos da curta fala do trono de 15 de janeiro de 1879 indispuseram vários parlamentares: primeiro, o tom autoritário contido no cumpre que decreteis; segundo, a determinação de que a reforma eleitoral devia ser feita mediante reforma constitucional, o que fechava a porta ao exame da alternativa de fazê-la mediante lei ordinária. A questão da resposta a ser dada à fala do trono aqueceu de tal maneira os ânimos, que a discussão sobre o projeto de reforma eleitoral do gabinete Sinimbu antecipou-se à sua entrada oficial na Câmara. Antes de passar ao exame dos projetos de reforma eleitoral e dos debates então travados a respeito dos mesmos, analisarei brevemente o contexto econômico e ideológico-político em que emergiu e se desenrolou a questão eleitoral.

\section{0 contexto da questão eleitoral: café, escravidão}

A questão eleitoral bem como a empreitada da reforma eleitoral cometida ao partido liberal tiveram lugar num contexto histórico muito particular, caracterizado, de um lado, por uma economia cafeeira ainda fundada predominantemente no trabalho escravo e, de outro, por um regime monárquico navegando entre o constitucionalismo e o absolutismo e defrontando-se, desde a origem, com ideias novas (liberais), agora de inclinação crescentemente republicana. Em síntese: café, escravidão e liberalismo. $\mathrm{O}$ único questionamento que se poderia dirigir à composição formada pelo concurso dessas três condições seria a de uma contradição 
entre liberalismo e escravidão. Seria uma contradição? Procederei por parte, iniciando pelos dois primeiros termos do referido trio: café e escravidão.

Ao ciclo da economia canavieira, com seu centro dinâmico no Nordeste, seguira-se o ciclo da mineração, assim descrito por Prado Júnior:

O INTERESSE da metrópole pelo Brasil e o desenvolvimento conseqüente de sua política de restrições econômicas e opressão administrativa tomarão considerável impulso, sobretudo a partir de princípios do séc. XVIII quando se fazem na colônia as primeiras grandes descobertas de jazidas auríferas. A mineração do ouro no Brasil ocupará durante três quartos de século o centro das atenções de Portugal e a maior parte do cenário econômico da colônia. Todas as demais atividades entrarão em decadência, e as zonas em que ocorrem empobrecem e se despovoam. Tudo cede passo ao novo astro que se levanta no horizonte; o próprio açúcar, que por século e meio representara o nervo econômico da colonização e sua própria razão de ser, é desprezado (PRADO JÚNIOR, 1970, p. 56).

Durante quase todo o século XVIII, a mineração - primeiro, o ouro; depois, os diamantes - polarizara as atenções. Os resultados foram a ocupação do centro do continente sul-americano, o deslocamento do eixo econômico dos grandes centros açucareiros do Nordeste (Pernambuco e Bahia) para o Centro-Sul (hoje, região Sudeste) e, por fim, em 1763, a transferência da capital da Bahia para o Rio de Janeiro. "De modo geral" - diz o autor - "é todo o centro-sul que, graças em grande parte à mineração, toma o primeiro lugar entre as diferentes regiões do país; para conservá-lo até hoje" (PRADO JÚNIOR, 1970, p. 64).

A fulgurante ascensão das minas teve como contrapartida a decadência da agricultura, agravada pela chamada política do "pacto colonial" adotada pelas grandes potências concorrentes de Portugal (PRADO JÚNIOR, 1970, p. 79). Com o declínio da mineração, ressurge novamente a agricultura, com destaque para o algodão, que veio somar-se à produção açucareira, para, em breve, sobrepujá-la, até que a queda dos preços no mercado internacional comprometesse ambos (açúcar e algodão), abrindo espaço para a ascensão do café.

Em estudo sobre a Província de São Paulo, ao tratar do retrocesso açucareiro e da expansão cafeeira, Sérgio B. de Holanda esclarece que, se a expansão do café vinha de longe, só chega à sua fase aguda em mea- 
dos do século XIX, quando o café toma, afinal, o lugar do açúcar como principal gênero de exportação da Província. “Tal processo - diz o autor - desenvolvera-se a partir do chamado norte, ou seja, do Vale do Paraíba, extensão natural da área cafeeira fluminense e dependente, economicamente, da Corte, muito mais do que da capital paulista". Diz ainda que tal expansão "Pouco tinha a ver [...] com a evolução da lavoura comercial na Província de São Paulo, que se efetuara de preferência na direção do Oeste, o Oeste da maior parte do século passado [XIX], que tem seu fulcro em Itu primeiramente, depois em Campinas" (HOLANDA, II. 2, 1979, p. 461).

Como observam Bethell e Carvalho, na época da independência (decênio de 1821 a 1830), o café já se havia firmado como a terceira mais importante cultura comercial do Brasil, vindo a superar o algodão e o açúcar no lustro seguinte (1831-1835), tornando-se, a partir daí, o principal produto de exportação e atingindo, por volta de 1850, quase metade do valor total das exportações (citado em BETHELL, 2001, p. 737-738).

Até o momento que aqui interessa - o da reforma eleitoral nos anos 1978-1881 -, havia plena coincidência entre os interesses do café e a continuidade do regime escravista. A própria concentração de escravos na lavoura cafeeira, operada entre a independência e o início da década de 1870, confirma a existência desse vínculo. "Os negros se concentravam nas províncias cafeeiras”, diz Emília Viotti da Costa, referindo-se a esse período.

Em 1823, Minas, Rio e São Paulo contavam 386 mil escravos, aproximadamente, enquanto Bahia, Pernambuco e Maranhão detinham, nessa mesma época, cerca de 484 mil. Cinquenta anos mais tarde, a situação se invertera. Estas contavam 346.237 escravos, enquanto as províncias cafeeiras reuniam quase oitocentos mil. (COSTA, 2007, p. 302)

Em São Paulo, essa concentração de escravos (via migração, uma vez que o tráfico internacional fora proibido em 1850) chegara a suscitar preocupação das autoridades provinciais, ao ponto de o presidente da província "solicitar um novo tributo sobre os escravos que entrassem na província", invocando como argumento "os riscos que adviriam do deslocamento dos escravos do norte para o sul do país". A referência era o que sucedera nos Estados Unidos (COSTA, 2007, p. 303).

No Brasil, a extinção da escravatura deu-se por etapas. A maior controvérsia teve lugar não quando da abolição, em 1888, mas no 
momento em que o gabinete conservador presidido pelo Visconde de Rio Branco propôs a chamada Lei do Ventre Livre, em 1871, "arrebatando desse modo a bandeira do abolicionismo das mãos dos liberais". Contrariamente ao encaminhamento dado então à questão servil por meio dessa lei, a classe social dominante "via no projeto um grave risco de subversão da ordem", porquanto: "Libertar escravos por um ato de generosidade do senhor levava os beneficiados ao reconhecimento e à obediência. Abrir caminho à liberdade por força da lei gerava nos escravos a idéia de um direito, o que conduziria o país à guerra entre as raças" (FAUSTO, 2003, p. 217-218).

\section{0 contexto da questão eleitoral: liberalismos neste lado do Atlântico}

Emília Viotti da Costa observa que os movimentos revolucionários americano e francês da segunda metade do século XVIII tiverem efeito revolucionário contagiante na América. Em relação ao Brasil, no entanto, a autora é de opinião que não se deveria exagerar tal influência em movimentos como os de 1789 (Inconfidência Mineira), 1798 (Conjuração Baiana), 1817 (Revolução Pernambucana), os quais se caracterizariam por "pobreza ideológica”. Bem diferentes da Europa eram as condições no Brasil. "Na Europa - diz a autora -, o liberalismo era uma ideologia burguesa voltada contra as Instituições do Antigo Regime, os excessos do poder real, os privilégios da nobreza, os entraves do feudalismo ao desenvolvimento da economia”. Bem outras eram as condições no Brasil:

No Brasil, as idéias liberais teriam um significado mais restrito, não se apoiariam nas mesmas bases sociais, nem teriam exatamente a mesma função. Os princípios liberais não se forjaram, no Brasil, na luta da burguesia contra os privilégios da aristocracia e da realeza. Foram importados da Europa. Não existia no Brasil da época uma burguesia dinâmica e ativa que pudesse servir de suporte a essas idéias. Os adeptos das idéias liberais pertenciam às categorias rurais e sua clientela. As camadas senhoriais empenhadas em conquistar e garantir a liberdade de comércio e a autonomia administrativa e judiciária não estavam, no entanto, dispostas a renunciar ao latifúndio ou à propriedade escrava. A escravidão constituiria o limite do liberalismo no Brasil. Em todos os movimentos revolucionários levantou-se o problema da escravidão. Apesar das eventuais divergências de pontos de vista entre os participantes, acabou prevalecendo sempre a opinião dos que eram contrários à emancipa- 
ção dos escravos. A idéia de revolução esbarrava sempre no receio de uma revolta de escravos. O comportamento dos revolucionários, com exceção de poucos, era freqüentemente elitista, racista e escravocrata (COSTA, 2007, p. 32).

De maneira semelhante, Lúcia M. M. P. Neves inicia seu texto sobre liberalismo político no Brasil dizendo que o século XIX "nasceu sob a égide do embate entre Antigo Regime e Luzes", para, adiante, ao tratar da revolução liberal vintista que pretendeu substituir, na Metrópole, "as práticas do antigo Regime pelas do liberalismo", dizer que tal revolução deve ser analisada "sob a ótica das mitigadas luzes ibéricas". Segundo a autora, "o ano de 1821 converteu-se, dos dois lados do atlântico, naquele da pregação liberal e do constitucionalismo, esboçando-se uma nova cultura política, cuja dinâmica, porém, acompanhou o ritmo do processo histórico mais amplo". E esclarece que a matriz dessa cultura política foi a Ilustração portuguesa, no que a Universidade de Coimbra, reformada em 1772, desempenhou papel fundamental. (NEVES. In: GRIMARÃES; PRADO, 2001, p. 7.77).

A dar-se razão à autora citada quando fala em "mitigadas luzes ibéricas", seria preciso ter abertura para a hipótese de que, no Brasil ainda Colônia e, logo a seguir, Império-Colônia e, logo a seguir, Império, essas luzes pudessem não passar de modestas candeias. Isso pode ser importante para se entender o tipo de liberalismo que aqui vingou no século XIX, pelo menos até o período da reforma eleitoral em exame.

Encarada a coisa no atacado, talvez a seguinte figura possa dar conta do liberalismo que acabou predominando no Brasil: fraque liberalburguês vestindo senhor de escravos. Só muito lentamente - e muito a contragosto - é que as elites brasileiras passaram a assimilar a ideia da abolição. Para Boris Fausto (2003, p. 233), a monarquia não ficou surda aos novos tempos, "embora as iniciativas de reforma tivessem muitas vezes efeitos até negativos para a sua sobrevivência". É que, em geral, segundo o autor, tais iniciativas conseguiam suscitar temor de ambos os lados: "pareciam insuficientes para as correntes reformistas e radicais aos olhos dos conservadores".

Penso que aqui se faz necessário um alerta. O fato de a reforma eleitoral (1881) haver acontecido antes da abolição da escravatura (1888) não deveria levar precipitadamente à conclusão de que foi mais fácil às elites brasileiras assimilar o voto direto do que abolir o trabalho escravo. 
Como se verá, o voto direto só se tornou tragável para as elites brasileiras ao alto preço da ampliação e do simultâneo endurecimento dos mecanismos de exclusão do povo do direito de voto.

Consumada, por assim dizer, a ascensão do café, o período da questão eleitoral torna-se também palco de uma mudança profunda no espectro dos atores políticos no país. Os saquaremas 3 , "conservadores de tipo antigo", representando Itaboraí o último espécime dessa estirpe, dão lugar a "conservadores de novo tipo", como os que completaram o decênio de governos conservadores inaugurado por Itaboraí, em 1868: o Visconde, depois Marquês de São Vicente (1870/71), o Visconde de Rio Branco (1871/75) e o Duque de Caxias (1875/78).

Se no período da Conciliação, conservadores e liberais se assemelhavam a tal ponto que os dois termos não constituíam mais do que etiquetas ${ }^{4}$ de identificação de uns e de outros, agora, nos gabinetes liberais de Sinimbu e Saraiva, mais uma vez as coisas parecem confundir-se. Se essa semelhança e confusão chegara ao ponto de os conservadores fazerem as vezes de liberais na Lei do Ventre Livre (1871), agora, na reforma eleitoral (1881), são os liberais que fazem as vezes de conservadores. Aliás, essa semelhança entre liberais e conservadores verificada no Brasil não haveria de constituir-se em caso único na América Latina, como bem se pode conferir na obra Cien años de soledad, de Gabriel García Márquez (2007, p. 278), onde se lê: "Fue por esta época que se oyó decir: 'La única diferencia actual entre liberales y conservadores, es que los liberales van a misa de cinco y los conservadores van a misa de ocho"'. Essa convergência entre liberais e conservadores no Brasil pode significar que a Câmara dos Deputados do final do Império estava bem a par do que vinha acontecendo na Inglaterra, onde o alargamento do acesso dos trabalhadores ao voto acabara sendo obra não do liberal Gladstone, mas do conservador Disraeli. Porém, com uma diferença fundamental: enquanto na Inglaterra, pelo Second Reform Act, de 1867, o conservador Disraeli, "o Luis Napoleão da Inglaterra", concedia "voto aos homens trabalhadores e direito de greve aos sindicatos" (SEAMAN, 1973, cap. 8) , no Império do Brasil, alguns anos mais tarde (1881), o liberal Saraiva haveria de reduzir, de maneira drástica, o já limitado acesso do povo ao voto e à participação política. 


\section{Liberalismo e voto popular}

Para se entender a aparente contradição no que se acaba de dizer, é importante lembrar que a tarefa atribuída aos liberais brasileiros tem desdobramentos para muito além da opção pelo voto direto, em substituição ao indireto. $\mathrm{Na}$ realidade, o problema não está no voto em si, mas no povo. Ou melhor, o problema não está propriamente na forma indireta ou direta do voto, mas nos riscos que as elites veem no eventual alargamento da participação do povo no processo político. $\mathrm{O}$ voto direto nas mãos do povo é que se constitui no verdadeiro problema para os membros da elite brasileira, independentemente da etiqueta que os identifique como liberais ou conservadores. A julgar pelo número de vezes que os deputados brasileiros invocaram a autoridade de John Stuart Mill para justificar a exclusão dos analfabetos do direito de voto, o pesquisador é levado a crer que estavam muito bem-informados sobre o que se passara recentemente e se passava na Inglaterra. Bradley (1980, p. 156), por exemplo, relata que, em 1866, uma demonstração de homens trabalhadores em favor da reforma eleitoral organizada pela Liga pela Reforma acabou pondo abaixo as grades do Hyde Park quando lhe foi negado acesso. A conclusão óbvia do autor - "Agora não havia dúvida que o povo queria votar" - devia estar soando em tom de ameaça nos ouvidos da Câmara brasileira, especialmente sabendo esta que os próprios conservadores da Ilha se apressaram em atender ao clamor popular. Aqui, talvez, ainda se pudesse prevenir!

Este ponto precisa ser explicitado. Primeiro, o voto não foi invenção da burguesia. O que a burguesia inventou e aquilo pelo que lutou foi o acesso de si mesma ao voto. Entenda-se: acesso da burguesia proprietária! O que ela sempre temeu - e por isso procurou sempre afastar, limitar ou pelo menos controlar - foi o acesso do povo ao voto, fosse este entendido como privilégio ou como direito.

Admitindo-se que John Locke é o fundador do liberalismo, ou pelo menos o seu mito fundador (GARANDEAU, 1998, p. 47), tem-se também de admitir que a luta da burguesia pelo acesso ao voto - ao privilégio do voto, como se entendia então! - antecedeu o grande teórico da Revolução Gloriosa de 1688. Com efeito, tratando das fontes da tradição democrática liberal, C. B. Macpherson deixa claro que, já no famoso debate travado em 29 de outubro de 1647 sobre a cláusula do sufrágio do primeiro Acordo do Povo, em Putney, na Inglaterra, ficou claro que havia acor- 
do entre as partes em dois pontos fundamentais quanto ao voto "universal": primeiro, que o voto se restringia aos homens adultos ("voto [masculino adulto] universal") e, segundo, que, qualquer que fosse o tipo de sufrágio a ser adotado ${ }^{6}$, ficavam sempre excluídos do voto os assalariados e os mendigos (MACPHERSON, 1979, p. 117-118). Segundo o autor, o próprio John Locke continuou sustentando a exclusão da classe trabalhadora do privilégio do voto, por entender que a classe operária, mais que todas as outras, era "incapaz de levar uma vida racional" e que, na Inglaterra, desde que houvera assalariados, "a suposição de sua incapacidade havia sido um princípio” (MACPHERSON, 1979, p. 238).

Diria que essa suposta incapacidade de ação política do não-proprietário (particularmente dos assalariados e pedintes) aparece de outra forma na obra mais famosa de Locke - Dois Tratados sobre o Governo. Na leitura do Segundo Tratado tem-se a impressão de que o termo povo, no texto de Locke, se refere expressamente à burguesia, aos proprietários no sentido burguês, por oposição à nobreza, uma vez que, segundo o autor, a sociedade política tem seu fundamento justamente na necessidade de defesa da propriedade. Diz ele:

[...] o poder político é aquele que todo o homem, possuindo-o no estado de natureza, passa às mãos da sociedade, e desta forma aos governantes que a sociedade estabeleceu, com o encargo expresso ou tácito de que seja utilizado para o bem desta e a preservação de suas propriedades (LOCKE, 1998, p. 538).

Seria o mesmo que dizer: para o bem da sociedade dos proprietários e a preservação de suas propriedades. Locke mesmo esclarece adiante, entre parêntesis, o que entende por propriedade: "(Por propriedade deve-se entender aqui, como em outros lugares, a propriedade que os homens têm sobre suas pessoas e bens)" (LOCKE, 1998, p. 541). Isso talvez ajude a entender tanto o alcance quanto os limites inerentes à afirmação do autor de que "cabe ainda ao povo um poder absoluto para remover ou alterar o legislativo quando julgar que este age contrariamente à confiança nele depositada" (LOCKE, 1998, p. 418. Grifos na fonte). Entenda-se: poder absoluto da burguesia proprietária para remover ou alterar o legislativo quando julgar que este age contrariamente à confiança nele depositada para garantir a segurança das pessoas dos proprietários e de suas propriedades! 


\section{Reforma eleitoral pela via da reforma constitucional (Projeto Sinimbu, 1879)}

Passo a sintetizar, aqui e no item seguinte, alguns aspectos relativos aos dois projetos liberais de reforma eleitoral e aos debates parlamentares que se travaram em torno deles, sem, no entanto, pretender fazer a história detalhada desse processo, o que ultrapassaria de muito os limites do presente trabalho. Para tal fim, apoio-me nos Anais da Câmara dos Deputados, referentes aos anos de 1878 a 1881, acessados em diferentes momentos a partir de janeiro de $2007^{7}$. Inicio com o projeto do Gabinete liberal Sinimbu, o qual dá entrada formal na Câmara em 13 de fevereiro de 1879, propondo a reforma eleitoral via reforma da Constituição de 1824. O texto do referido projeto é curto e grosso, propondo, primeiro, a reforma dos artigos 90, 91, 92 e 93 da Constituição, "para o fim de serem as nomeações dos deputados e senadores para a assembléia geral, e dos membros das assembléias provinciais, feitas por eleição direta”, e segundo, a reforma do artigo 94, "para o fim de só poderem votar os que, sabendo ler e escrever, tiverem por bens de raiz, capitais, indústria, comércio ou emprego, a renda liquida anual que for fixada em lei, nunca inferior a quatrocentos mil reis" (CÂMARA, Anais, 13/02/1879, p. 492. Acesso em: 16 jan. 2007. São meus grifos).

O caráter excludente da proposta de alteração do artigo 94 da Constituição imperial é logo percebido por alguns deputados. Com efeito, o projeto, ao mesmo tempo em que mantinha e duplicava o censo, elevandoo de duzentos para um mínimo de quatrocentos mil réis, podendo ser esse valor aumentado por lei ordinária, propunha uma segunda exigência - a de a pessoa saber ler e escrever para poder votar. Os debates mais candentes e interessantes em termos de sua relação com o voto dos analfabetos e a educação escolar no país são os suscitados na Câmara por esse primeiro projeto. Tais debates contam com a participação do que talvez tenha sido o grupo mais notável de tribunos a se enfrentarem na Câmara dos Deputados em todo o Império, envolvendo figuras como José Bonifácio o Moço, Joaquim Nabuco, Saldanha Marinho, Silveira Martins e Rui Barbosa.

Antes mesmo de sua apresentação na Câmara, o projeto suscitara temores e críticas de parte da minoria liderada por José Bonifácio o Moço. Membro dessa minoria, Cândido Oliveira, por exemplo, manifestara o temor de que o Ministério estivesse querendo "despojar o povo do seu direito" e “criar uma classe privilegiada" (CÂMARA, Anais, 21/01/1879, p. 82. Acesso 
em 17 jan. 2007). O deputado Prado Pimentel, por sua vez, criticara o gabinete liberal por haver restringido o ideário liberal à eleição direta, dizendo que não concorreria com seu voto "para que se seqüestrem os direitos dos cidadãos brasileiros”, que deles gozavam há longos anos, em virtude da Constituição do Império (CÂMARA, Anais, 23/01/1879, p. 97. Acesso em: 17 jan. 2007).

É de José Bonifácio o Moço que parte a crítica mais dura à proposta de reforma eleitoral que seria apresentada na Câmara três dias depois. "Uma constituinte - diz o deputado - só convocada para restringir direitos políticos, e restringi-los nos termos indicados por lei ordinária!". Manifesta-se repetidamente contra o aumento do censo e particularmente contra a exclusão dos analfabetos num país "onde oito ou sete décimos da população não sabe ler", fatores estes que, combinados, acabariam por reduzir enormemente o eleitorado:

As restrições pretendidas elevando o censo arbitrariamente e excluindo os analfabetos, combinadas entre si, têm um vasto alcance: reduzem o eleitorado a muito menos do que seria conveniente e excluem do direito de voto uma enorme e reconhecida massa de cidadãos brasileiros, até hoje no gozo desse direito. É grave a questão; é a constituinte sem liberdade (CÂMARA, Anais, 10/02/1879, p. 430-431. Acesso em: 17 jan. 2007. São meus os grifos).

Já discutindo o projeto, que fora apresentado na Câmara em 13 de fevereiro de 1979, Saldanha Marinho diz que o presidente do Conselho de Ministros, ao ser chamado para organizar um gabinete liberal, deveria ter sido mais explícito e mais enérgico, apresentando o programa do partido liberal e dizendo em que condições este poderia governar. Segundo ele, "o partido liberal não devia prestar-se apenas como instrumento da vontade acanhada da coroa". E prossegue: "A constituinte não pode alterar a significação das palavras. Ora, tirem-se os que não têm renda líquida, tirem-se os que não sabem ler, a que fica reduzido o direito de votar? É isto liberal? Os conservadores não o teriam feito melhor. Talvez mesmo nem aceitem tão avultado presente". E pergunta: "se o projeto é do partido liberal, se não é ele apenas da vontade da coroa, como é que se pretere o que de liberal se podia estabelecer?" (CÂMARA, Anais, 23/04/1879, p. 683-684. Acesso em: 01 jul. 2007).

Gavião Peixoto, embora, em princípio, considere razoável a exclusão dos analfabetos na eleição de um único grau, argumenta que, no 
Brasil, no mínimo $3 / 4$ dos homens adultos brasileiros são analfabetos. No seu entendimento:

É preciso fugir dos extremos, aceitando o justo meio, que parece ser, quanto à renda, o censo da constituição [200 mil réis], e quanto aos analfabetos o direito de votar. Ao menos enquanto a sociedade, por sua parte, não tiver cumprido o dever fundamental de por a instrução ao alcance de todo o mundo (CÂMARA, Anais, 25/04/1879, p. 721. Acesso em: 01 jul. 2007. São meus os grifos).

E àqueles que argumentavam que John Stuart Mill sustentava a exclusão dos analfabetos do direito de voto, ele responde dizendo que o mesmo Stuart Mill dissera estas sensatas palavras: "Quando a sociedade não cumpriu o seu dever, tornando esse grau de instrução acessível a todos, há por certo injustiça em privar do voto os que não saber ler e escrever" (CÂMARA, Anais, 25/04/1879, p. 721. Acesso em: 01 jul. 2007. São meus os grifos).

Para José Bonifácio, o projeto de Casansão Sinimbu “ergue o estandarte do privilégio no posto onde devera erguer o da igualdade. (Muito bem)". E prossegue: "O projeto que se discute é a negação do governo parlamentar, é o suicídio moral de um partido no momento da vitória; não é a bandeira da reforma é a reforma da bandeira [liberal] (Apoiados)." Após interrupção, restabelecida a ordem nas galerias com apoio da comissão de polícia, José Bonifácio é chamado a prosseguir em seu discurso. "Por que garantis vós o exercício do voto?", pergunta o deputado. Ele mesmo responde: "É certamente porque a garantia do acerto está no exercício coletivo do direito. A coletividade não precisa que lhe determinem capacidade alguma; é capaz porque é sociedade; é capaz porque governa-se". E prossegue mostrando as diferentes formas que o povo, mesmo analfabeto, tem de se instruir: "O voto individual não é exclusivamente o resultado do conhecimento próprio; o votante instrui-se na conversação diária, na prédica do vigário, no juízo dos tribunais, na discussão das câmaras, na execução das leis, na leitura própria ou alheia da imprensa, nas reuniões políticas, em tudo que o cerca”. José Bonifácio rebate mais uma vez os pressupostos de falta de discernimento e de incapacidade invocados pelo governo em favor da exclusão dos analfabetos. Segundo o deputado, as únicas condições do voto são o discernimento e a vontade, sendo que o discernimento depende apenas da própria inteligência. E argumenta: "Nem o saber ler e escrever, nem a ciência, nem a 
instrução de qualquer natureza, nem a vida a que o homem se dedica, o criam e determinam”. Ainda segundo o deputado José Bonifácio, “pelo censo e pela exclusão dos analfabetos, o projeto do governo finge mandatários sem mandato, constituindo uma fração mínima da população senhora de todos os habitantes do Império". E acrescenta que, mesmo com mandato restrito, "eles [os excluídos] não renunciaram o direito de cidadãos brasileiros" e poderão, por isso, "pedir contas aos mandatários infiéis". Como? "Só lhes resta opor força à força. O mandato restrito, transformado em mandato nacional, dá como conseqüência o direito à insurreição". E, em tom premonitório, conclui:

Em nome da monarquia constitucional representativa; em nome da câmara que vos apóia, e que sem dúvida aceitará contente o vosso projeto modificado, senhores ministros, eu vo-lo peço: não arredeis do trono a confiança da nação, honrai as esperanças do povo, libertando a ação da constituinte (CÂMARA, Anais, 28 abr. 1879, p. 748-762. Acesso em: 29 jun. 2007).

E os anais registram: "(Rompem clorosos e prolongados aplausos nas galerias e no recinto da câmara. O orador é abraçado por grande número de Srs. Deputados) A discussão fica adiada pela hora" (CÂMARA, Anais, 28 abr. 1879, p. 748-762. Acesso em: 29 jun. 2007).

No dia seguinte ao discurso de José Bonifácio, é Joaquim Nabuco que entra em cena para apostrofar os próprios colegas de partido. Em sua palavra, o partido conservador convocara o parlamento para garantir a liberdade àqueles que ainda iam nascer do ventre escravo. E que faz o partido liberal? “... depois de dez anos de oposição, convoca o seu parlamento, não para alargar o direito de sufrágio àqueles que ainda não se acham na posse dele, mas para tirá-lo a um grande número daqueles mesmos que nos mandaram a esta casa". Os Anais registram que essas palavras foram acompanhadas de "Não apoiados". Nabuco vê um grande perigo no querer fazer-se da reforma eleitoral matéria constitucional. Tal perigo, segundo ele, está no precedente; está no fato de, pela primeira vez depois de 40 anos, se querer convocar uma constituinte para tocar na constituição; está ainda em se fazer isso "não no sentido liberal, não para alargar direitos, não para transformá-la no sentido das aspirações de uma democracia que cresce”, mas, ao contrário, "para mutilá-la, para tirar-lhe aquilo que ela tinha de expansivo e de liberal, para torná-la a bandeira dos nossos adversários, para impopularizar um partido que em toda a parte é 
o do povo e para tirar a classes inteiras o direito de voto (Apoiados)". E, de forma irônica, dirige-se àqueles que não sabem ou não querem fazer o cálculo de quantos resultarão excluídos do direito de voto com a pretendida reforma: "A minha aritmética nesse ponto não falha; [...] porque, segundo a opinião do Sr. Stuart Mill, que prevalece nesta casa, não são só os analfabetos que não devem votar, são também os que não conhecem os princípios da aritmética”. E aos pretensos moralizadores do processo eleitoral pergunta:

Como é que essas classes vêm hoje perante o país, escandalizadas, cobrindo as faces de vergonha, dizer que a responsabilidade dessas corrupções devem reverter sobre esses pobres homens, que as não podiam pagar; que a culpa dessas atas falsas pertence aos analfabetos, que não as podiam escrever, que o crime dessas qualificações fraudulentas, dessas duplicatas imaginárias, dessas apurações escandalosas, de todo o nosso regime eleitoral, enfim, é obra daqueles que, no mais, não foram senão seus cúmplices? (CÂMARA, Anais, 29/04/2007, p. 763-773. Acesso em: 01 jul. 2007).

E, em tom de vaticínio, alerta: “... quando tiverdes tocado nos direitos de um só cidadão, não podeis estar certos de que não tocarão nos vossos"; e, como se isso não bastasse, acrescenta: "nem podeis saber até que ponto chegará a audácia do partido conservador, se o liberal tiver a ousadia de restringir os direitos do povo". Já concluindo, e lembrando a bandeira liberal e o dístico "Reforma ou revolução" nela inscrito, Joaquim Nabuco nega que seja a bandeira liberal aquela que tremula nas mãos do Sr. Presidente do Conselho. Os Anais registram (Aplausos das galerias. Muito bem, muito bem. O orador é cumprimentado pelos seus colegas.) (CÂMARA, Anais, 29/04/2007, p. 763-773. Acesso em: 01 jul. 2007).

Paralelamente às críticas, levantam-se também vozes em favor do projeto. Para o Sr. Olegário, por exemplo, a questão de fundo é a da eleição direta. O resto, como a exclusão ou não dos analfabetos, não é mais que uma "questão de forma". Na realidade, o deputado parecia estar mais preocupado com as "agitadas comoções populares", em que dizia dominarem o "cacete dos Bijus e Bocas-Negras" e a "navalha dos capoeiras"! (CÂMARA, Anais, 27/01/ 1879, p. 213-225. Acesso em: 17 jan. 2007).

Também em defesa do projeto, o deputado Florêncio de Abreu entra no debate com uma peça preciosa para o que aqui interessa, precisamente porque reveladora do processo de estigmatização do analfabetis- 
mo e da condição de analfabeto que então começava a ter lugar. Respondendo ao deputado Prado Pimentel, que advertira que elevar o censo seria promover a mais estúpida das aristocracias, a do dinheiro, ele responde: “[...] entregar o direito de voto, cuja responsabilidade é tão grande, à ignorância e ao pauperismo é que seria criar a mais degradada das democracias". O deputado entende que a reforma eleitoral só consultará as verdadeiras conveniências públicas "se considerar que na instrução e em uma certa abastança estão em regra representadas a capacidade e a independência precisas para a escolha dos representantes do país (Apoiados)" (CÂMARA, Anais, 27/01/1879, p. 319. Acesso em: 17 jan. 2007. São meus os grifos). Já está aí claramente esboçada a associação direta e explícita da condição de analfabetismo com o estado de ignorância, de pauperismo, de dependência e de incapacidade. É essa associação, principalmente, retomada dias mais tarde pelo então Ministro da Justiça, o Sr. Lafayete, que será utilizada por mais de um século para legitimar a exclusão dos analfabetos do direito de voto.

O Inácio Martin invoca, também ele, a autoridade de Stuart Mill em defesa da exclusão dos analfabetos, desafiando: "Os nobres deputados não quererão por certo ser mais liberais do que Stuart Mill” (CÂMARA, Anais, 23/05/2007, p. 362. Acesso em: 01 jul. 2007).

Em 28 e 29 de maio, o debate esquenta novamente com as intervenções do presidente do Conselho de Ministros e do Ministro da Justiça, em defesa do projeto, e de José Bonifácio, contra o projeto. O Sr. Sinimbu, presidente do Conselho, reafirma a incapacidade do analfabeto para votar, no que é muito aplaudido: "Quanto à condição de saber ler e escrever, creio, senhor presidente, que é o menos que se pode exigir como sinal de capacidade daquele que tem de concorrer diretamente pra a escolha dos representantes da nação (Muitos apoiados)". Ao final, lê-se: "Vozes: - Muito bem; muito bem. O orador é muito felicitado)" (CÂMARA, Anais, 28/05/2007, p. 422-428. Acesso em: 29 jun. 2007).

Segue, na mesma sessão, novo discurso de José Bonifácio o Moço, o qual argumenta que, se para votar não basta querer e discernir; se é preciso condição especial de capacidade, essa lógica levaria a uma situação absurda assim descrita: "Excluís os analfabetos, porque não sabem ler e escrever; excluís os que não sabem ler e escrever, porque não sabem calcular; excluís os que não sabem calcular, porque não são doutores; excluís os que são doutores, porque há quem saiba mais do que eles 
(Riso)". E lembra que, na antiga Roma, os fidalgos tinham copistas; os escravos copiavam (CÂMARA, Anais, 28/05/2007, p. 428-433. Acesso em: 29 jun. 2007). Referindo-se à autoridade de Stuart Mill, tantas vezes invocado nos debates em favor da exclusão dos analfabetos, diz:

A opinião dos escritores, citados nesta casa para sustentar a famosa exclusão, não tem o valor que se lhe empresta; porque parte do ensino obrigatório e gratuito, e assenta todo seu raciocínio na generalidade ou facilidade da instrução primária. No Brasil não raciocinariam do mesmo modo. Uma das províncias do Império em que a instrução está mais generalizada é o Rio de Janeiro. Pois bem, leia-se o relatório do ilustre Sr. Visconde de Prados, e ver-se-á qual a distribuição das escolas e quais as facilidades que lá mesmo se encontram para aprender a ler e escrever. Há perímetro de tal extensão, em que os moradores das extremidades precisariam do dia inteiro para ir às escolas e voltar das apetecidas lições. (CÂMARA, Anais, 28/05/2007, p. 433. Acesso em: 29 jun. 2007).

O deputado prossegue argumentando que o caminho reto seria instruir os que não sabem ler e escrever ou proporcionar-lhes tempo e meios para saber. Segundo ele, o projeto inverte os dados do problema. E pergunta:

Não é a lei obrigatória para todos depois de promulgada, até mesmo para os analfabetos? Não presumimos nós ciência porque em uma sociedade organizada a conversação diária, as reuniões, a imprensa, os julgamentos dos tribunais, a publicidade das sentenças, e tantos outros meios fornecerão ao homem o conhecimento da lei? Não o punis, se a viola, ainda que não pudesse conhecer pela leitura o texto da lei? Porque então o excluís de concorrer para sua formação, pelo seu voto? (CÂMARA, Anais, 28/05/2007, p. 433-434. Acesso em: 29 jun. 2007).

Dirigindo-se ao presidente da Câmara, diz que "é uma verdadeira ilusão o que se pretende - purificar as urnas, excluindo a nação de votar". Já concluindo, desfere duro golpe no projeto, quando diz: "Neste Império, sem mestres e sem discípulos, quando as estatísticas falam tão alto, vós fechais para o povo a grande escola do voto!" (CÂMARA, Anais, 28/05/2007, p. 434, Acesso em: 29 jun. 2007).

Em síntese, para José Bonifácio: 1. excluir os analfabetos do direito de voto não se justifica num país sem escolas; 2. é inaceitável o princípio da capacidade para votar, seja em si mesma, seja medida pela 
condição de saber ler e escrever; 3. a própria participação política é uma escola, e negar ao povo o direito de voto é fechar-lhe a grande escola do voto; 4. a exclusão dos analfabetos pretendida pelo projeto representa um cativeiro político para as massas.

No dia seguinte à fala de José Bonifácio, o Ministro da Justiça, o Sr. Lafayette, sai em defesa do projeto do governo. Repisa no principio de que, para votar, o cidadão "deve ter certo discernimento intelectual (apoiados), deve ter a capacidade suficiente para compreender e conhecer os interesses coletivos do Estado (apoiados) e para julgar da aptidão dos candidatos...”. Diz que a capacidade eleitoral requer também independência pessoal do eleitor (a ser comprovada com a renda). Para o ministro, "inteligência que não sabe ler e escrever, permanece como que fechada em um círculo de ferro, contrai-se e não toma desenvolvimento"; a inteligência que é condenada a tal obscurantismo "não pode formar juízo claro sobre os interesses coletivos da sociedade". Mas o que mais interessa é a citação que segue, em que o ministro inaugura, por assim dizer, o rosário daquilo que, quase um século mais tarde (em 1968, em texto escrito no Chile), Paulo Freire (2001, p. 15) chamaria de "concepções distorcidas" sobre o analfabetismo, ainda hoje correntes, e a que mais recentemente se chamou de "desconceitos" a respeito de analfabetismo (FERRARO, 2004). Mas, que disse, afinal, o ministro Lafayette? Primeiro, põe em dúvida as estatísticas: "Senhores, tem-se dito que neste país 9/10 da população compõe-se de analfabetos. Se as estatísticas oficiais dizem semelhante cousa, pela minha parte direi que as estatísticas são errôneas". O ministro tenta ilustrar isso nomeando províncias por ele conhecidas, estabelecendo-se tumulto. Restabelecida a ordem, prossegue o ministro: "Mas, admita-se, senhores, que oito décimos da população do Império se compõe de analfabetos, eu pergunto-vos? - a ignorância, a cegueira, porque se torna vasta e numerosa, porque se generaliza, adquire o direito de governar? (Apoiados)". E proclama: "Se há no Império oito décimos de analfabetos, eu vos direi, esses oito décimos devem ser governados pelos dois décimos que sabem ler e escrever". Para o ministro, o grupo liberal que se opunha ao projeto liberal não representava mais que "o mau humor do partido", e os deputados não se deviam deixar iludir. A anotação na ata ao final da fala do ministro: "(Muito bem; muito bem. O orador é felicitado pelo Sr. Presidente do conselho e por quase todos os Srs. deputados presentes)", antecipa o destino do projeto (CÂMARA, Anais, 29/05/2007, p. 453-451. Acesso em: 29 jun. 2007). 
No final da sessão do dia 29, são postas em votação e rejeitadas pela maioria todas as propostas de emenda ao projeto de reforma constitucional, passando este para a terceira discussão. Finalmente, em 9 de junho de 1879, encerrada a terceira discussão, o projeto é posto em votação, tendo 81 votos favoráveis e 16 contrários, sendo então encaminhado à consideração do Senado. Entre os 16 votos contrários, figuram nomes que defendiam posições diversas, tais como: manutenção do censo constitucional de duzentos mil réis, voto dos analfabetos, voto dos acatólicos, voto dos nacionalizados. Votaram contra também os dois ex-ministros, Silveira Martins e Barão de Vila Bela, do Gabinete Sinimbu, demitidos por defenderam o voto dos acatólicos e dos nacionalizados.

Depois da aprovação do projeto na Câmara, o deputado Rui Barbosa manifesta-se dizendo que o Brasil podia orgulhar-se de duas coisas: de não ter classes sociais ("classes não as temos") e de portar, inoculado nos hábitos, nas tendências, nas necessidades populares, o "gênio da igualdade". Quanto à reforma eleitoral proposta, manifesta-se plenamente favorável tanto à elevação do censo, que ele passa a chamar de censo pecuniário, para quatrocentos mil réis, quanto à introdução da condição de saber ler e escrever, que ele passa a chamar de senso literário (CÂMARA, Anais, 10/06/1879, p. 129. Acesso em: 11 nov. 2008).

\section{A reforma eleitoral por lei ordinária (Projeto Saraiva, 1880)}

Derrubado no Senado, o projeto de reforma eleitoral pela via da reforma da Constituição arrastou consigo o próprio governo Sinimbu. Restou ao novo governo (Gabinete Saraiva) o caminho da reforma por lei ordinária. Apresentado na Câmara em 29 de abril de 1880, o novo projeto é submetido à apreciação de Comissão Especial, a qual, em 25 de maio do mesmo ano, apresenta seu parecer, acompanhado de um projeto substitutivo que conta com o consentimento de Saraiva. Dos 18 membros que assinaram o parecer, seis o fizeram com restrições, entre os quais Saldanha Marinho, Joaquim Nabuco e Francisco de Sá (CÂMARA, Anais, 25/05/1880, p. 233-241. Acesso em: 10 jan. 2007).

O fato é que, apesar dessas restrições, o governo Saraiva consegue construir um grande consenso liberal em torno do novo projeto. Alguns pontos merecem destaque. 1 . O projeto estende efetivamente o 
direito de voto, na medida em que define como eleitor todo cidadão brasileiro, nato ou naturalizado, católico ou acatólico, ingênuo ou liberto, compreendido nos parágrafos $1^{\circ}$ a $5^{\circ}$. do artigo $6^{\circ}$. da Constituição do Império, que esteja no gozo de seus direitos políticos, que seja maior de 21 anos, com exercício efetivo dos direitos civis, e que possa comprovar, pelas formas previstas no projeto, renda anual não inferior a 200 mil réis ou que satisfaça algum outro critério previsto no projeto, como ser pessoa habilitada com diploma científico ou literário, ser clérigo de ordens sacras etc. 2. O projeto mantém o censo constitucional de 200 mil réis, em vez do mínimo de 400 mil pretendido pelo projeto anterior, mas ardilosamente aperta de tal maneira o torniquete dos mecanismos de comprovação de tal renda, que não é difícil a alguns deputados (poucos!) divisar o alto poder de exclusão que esses mecanismos haveriam de exercer sobre um eleitorado já restrito. 3. Mesmo sem excluir explicitamente os brasileiros que não sabiam ler e escrever, o projeto introduz esse critério de exclusão pela via indireta, na medida em que a pessoa habilitada a votar precisa escrever de próprio punho o nome do candidato escolhido e, além disso, assinar a ata, no que alguns deputados - poucos! - preveem que o resultado será o mesmo que se obteria pela exclusão explícita dos analfabetos contida no projeto Sinimbu. 4. O projeto qualifica as pessoas de baixa renda e as analfabetas como menos civilizadas, dependentes e politicamente incapazes.

O depoimento de Saldanha Marinho ajuda a entender o grande consenso liberal formado em torno do novo projeto. Ele começa elogiando o ministro Saraiva por haver-se apartado da postura autoritária - "do crê ou morre" - de seu predecessor. Destaca a seguir alguns avanços reais em relação ao projeto anterior: "O projeto nos oferece eleição direta, distritos de um só deputado, admissão dos acatólicos, dos ingênuos e libertos e dos naturalizados à elegibilidade". Assim, de duro crítico do projeto anterior, o Sr. Saldanha Marinho manifesta-se agora entusiasmado com o novo projeto, a ponto de chamá-lo de "magnífico". Mas, por que, então, o deputado faz restrições ao projeto Saraiva? Por entender que, se adotado o processo de prova de renda previsto no projeto (um "jogo de provas difíceis especiais, e não genéricas"), "o número de eleitores [...] ficará limitadíssimo, e nem exprimirá a maioria da nação", no que vai uma "perfeita espoliação". Além disso, o deputado manifesta-se criticamente em relação à exclusão do analfabeto: primeiro, porque, segundo ele, não é no proletariado, no pobre, na 
massa popular, no povo analfabeto "onde a corrupção se ostenta mais, onde com mais cinismo é professada"; segundo, porque, "Se [o projeto] não diz claramente que o analfabeto não tem voto, implicitamente o estabelece, quando determina que o eleitor (antigo votante ou atual votante) escreva e assine um recibo, e escreva ele mesmo a sua cédula" (CÂMARA, Anais, 01/06/1880, p. 325-332. Acesso em: 09 jan. 2007. Grifo na fonte). O deputado diz que considera iníqua tal providência, decretada assim de chofre, e que, por isso, a combate. Insurge-se contra a exigência de saber ler e escrever para poder votar num país sem escolas, posição que é reforçada pela intervenção do Deputado Galdino das Neves: "Para nove milhões de habitantes há quatro mil escolas". Para Saldanha Marinho, se o projeto não é franco na exclusão dos analfabetos, implicitamente estabelece a condição de saber ler e escrever, na medida em que exige recibos e assinaturas do próprio eleitor (CÂMARA, Anais, 01/06/1880, p. 325-332. Acesso em: 09 jan. 2007). Na realidade, o Senado se encarregaria de tornar explícita tal exclusão, como se pode conferir na Lei Saraiva (1881).

Em defesa do projeto, como que a título de fechamento, intervém no debate o deputado Rui Barbosa, com um longo e inflamado discurso. Baste destacar alguns pontos de sua fala. Em sua opinião, todos quantos contraditavam o pensamento do projeto "alteravam a compleição do seu sistema, inoculando-lhe um vício orgânico e fatal: a relaxação das provas". O deputado rejeita a acusação de que o projeto exclui o operário, as classes produtoras, o elemento popular. Note-se particularmente a preocupação do deputado Barbosa em demonstrar que, mesmo que alguns não possam votar, o projeto não contém qualquer exclusão de classes (CÂMARA, Anais, 21/06/1880, p. 353-354. Acesso em: 09 jan. 2007. Grifos na fonte: phosphoros). Afinal, como se viu antes, o deputado já dissera que o Brasil de 1879 desconhecia classes sociais ("classes não as temos") e que tinha inoculado em si o "gênio da igualdade". O discurso de Rui Barbosa atesta que não é nenhum anacronismo dizer que a questão de classes esteve presente de forma explícita nas discussões dos projetos de reforma eleitoral para introdução do voto direto. Embora, é claro, o deputado tivesse horror a essas categorias desirmanadoras!

Tudo leva a crer que a manifestação de Rui Barbosa nessa altura da tramitação do projeto na Câmara representa, a um só tempo, a consolidação definitiva do grande consenso, salvas poucas discordâncias, assim como a tranquilização da consciência da maioria liberal. Tudo na justa 
medida do liberalismo brasileiro de então. Nessa mesma linha vai a manifestação do então Ministro de Estrangeiros, o Sr. Pedro Luiz, para quem o que antes era "ler e escrever" fica agora reduzido a mera "formalidade de assinar o nome". Nenhum peso, portanto, em sua consciência liberal! (CÂMARA, Anais, 23/06/1880, p. 388-389. Acesso em: 09 jan. 2007).

O fato é que, com tramitação fácil pela Câmara e pelo Senado e com explicitação da exclusão dos analfabetos do direito de voto, o projeto é transformado na Lei n. 3.029, de 9 janeiro 1881, levando o nome de Lei Saraiva. Como já se disse antes, a exclusão dos analfabetos do direito de votos manteve-se, no país, por mais de um século, só sendo superada com o "Emendão" de 1985 e a Constituição de 1988.

\section{Brasil versus Argentina: a título de conclusão}

Como relata Fernando de Azevedo, no Brasil Império, o Ato Adicional de 1824 transferira para as assembleias provinciais o encargo de regular a instrução primária e secundária, deixando à administração nacional apenas o ensino superior no país e a organização escolar no Município Neutro. A reforma constitucional de 1834, em vez de solucionar, acaba agravando o problema, na medida em que torna impossível sua solução dentro dos quadros constitucionais. O que daí resulta é descrito em termos sombrios pelo autor: "Nenhuma perspectiva, daí por diante, para uma política educacional de larga envergadura. A educação teria de arrastar-se, através de todo o século XIX, inorganizada, anárquica, incessantemente desagregada" (AZEVEDO, 1963, p. 566-568).

Já em relação ao período que aqui interessa, Fernando de Azevedo, referindo-se agora especificamente às reformas educacionais realizadas desde o decreto de Couto Ferraz (1854), o "organizador", até as de Leôncio de Carvalho (1878 e 1879), o “inovador”, não vê nelas mais do que influências transitórias dos gabinetes ministeriais do momento:

Nenhum projeto de reforma geral com unidade orgânica de concepção e de plano. Faltava solidez à própria base dessas iniciativas oficiais que, limitadas ao ensino superior do Império e ao ensino primário e secundário da Corte, era como que empresas que se propusessem a levantar, sobre velhos alicerces de pouca profundidade, uma larga e pesada construção (AZEVEDO, 1963, p. 599$)$. 
É nesse contexto - de um país sem escolas e, mais que isso, sem um sistema nacional de ensino público - que acontece a Lei Saraiva, de 1881, a qual introduz o voto direto no Brasil, mas com o afastamento das grandes massas do direito de voto. O povo, se quisesse votar, teria de comprovar situação de relativa "abastança" e, além disso, aprender a ler e escrever! No entanto, nem o ensino se tornara obrigatório, nem o Estado oferecia escolas públicas gratuitas na quantidade requerida.

Assim, no Brasil, o ministério Saraiva estabelece, em 1881, uma reforma eleitoral que irá excluir por mais de um século a imensa massa de analfabetos, sem que efetivamente, num prazo previsível, se defina e implante um sistema escolar nacional, público, gratuito e obrigatório, capaz de alfabetizar a população e de, assim, dar-lhe acesso ao voto.

Enquanto isso, exatamente no período da reforma eleitoral no Brasil (final dos anos 1870 e início dos anos 1780), no país vizinho, a Argentina, opta-se e efetivamente passa-se a trilhar caminho bem diferente, também lá em nome dos princípios liberais. Mas com uma diferença fundamental. Enquanto, no Brasil, os deputados partidários dos projetos Sinimbu e Saraiva invocavam repetidamente a autoridade do liberal inglês John Stuart Mill para justificar a exclusão dos analfabetos do direito de voto, a Câmara argentina voltava sua atenção para o que se passava na França do início da década 1880, mais particularmente, como ensina Gregório Weinberg, "para os intensos debates, registrados na França, em torno da gratuidade, da obrigatoriedade e da neutralidade da escola pública, os quais culminaram com a sanção das leis de 16 junho de 1881 e de 28 de março de 1882, cujo grande inspirador foi Jules Ferry". E o autor acrescenta que aquela legislação deixou marcas duradouras para além das fronteiras da França, e que a própria Argentina foi alcançada pelo "eco retumbante e reconhecível" daquela polêmica (WEINBERG, 1984, p. IX).

Assim, no país vizinho, depois do enorme retrocesso registrado sob o regime de Juan Manuel de Rosas (1829-1852) ${ }^{8}$, retoma-se, a partir de Domingo Faustino Sarmiento, primeiro como presidente (1868-1874) e depois (a partir de 1881) como superintendente do Conselho Nacional de Educação, o caminho aberto muito antes por Manuel Belgrano e Rivadavia, depois interrompido por Rosas. São enfáticas as palavras de Weinberg a respeito: 
Se o trabalho da época rosista não suporta comparação com a rivadaviana, quando a comparamos com a sarmentiana a diferença se torna muito chocante. Porque o autor de Facundo parece um iluminado, um obcecado pela educação popular; via a solução de todos os problemas nesta fórmula mágica: “educar o soberano". (WEINBERG, 1984, p. IV)

As consequências dessas duas políticas contrastantes em relação à educação popular (à escola pública, obrigatória e gratuita) podem ser avaliadas pelo confronto das diferentes trajetórias do analfabetismo nos dois países. Na Argentina, o número de analfabetos, que era de cerca de 780 mil no censo de 1869, aumentou, sim, nas décadas seguintes, mas só até o censo de 1914, quando atingiu o número aproximado de 1,8 milhões, cerca de 2,5 vezes o número inicial, com diminuição rápida a partir de então. No Brasil, ao contrário, o número de analfabetos entre as pessoas de 5 anos ou mais, que era de 7,3 milhões no censo de 1872 , continuou crescendo por mais de um século, passando sucessivamente para 10,1 em 1890; 18,6 milhões em 1920; 21,3 milhões em 1940; 24,9 milhões em 1950; 27,6 milhões em 1960 e 30,7 milhões em 1970, até atingir o ponto máximo de 32,7 milhões em 1980, o equivalente a 4,5 vezes o número inicial. (VASCONI; RECA, 1967, p. 74, Quadro n. 1; FERRARO, 2002, Tabela 1).

A observação penetrante de Fernando de Azevedo (1963, p. 773) a seguir transcrita ajuda a entender por que a educação popular não podia interessar ao tipo de sociedade que se constituíra no Brasil: "Nessa sociedade [brasileira], de economia baseada no latifúndio e na escravidão, e à qual, por isso, não interessava a educação popular, era para os ginásios e as escolas superiores, que afluíam os rapazes do tempo com possibilidades de fazer os estudos" (AZEVEDO, 1963, p. 573).

No Brasil, um país sem escolas, a exclusão do povo analfabeto do direito de voto tinha o alcance prático de afastar, dentro do futuro previsível, qualquer inédito viável (FREIRE, 1979, p. 110) que pudesse ser divisado e buscado para superar a ordem estabelecida. Assim, a Lei Saraiva teve também um efeito tranquilizador para as elites brasileiras, especialmente aquelas ligadas aos interesses agrários, sempre muito fortes no país. E os discursos sobre a importância da escola e da alfabetização do povo? Uma coisa parece certa: se, apesar de tudo, a escola foi acontecendo, ela só aconteceu porque o povo a buscou, porque os movimentos sociais a exigiram, não por iniciativa das elites brasileiras, com destaque, aqui, para os interesses agrários. 
A leitura de Facundo: civilização e barbárie no pampa argentino 9 , obra clássica de Domingo Faustino Sarmiento (1996), poderia levar a uma associação indevida entre o papel desempenhado pelas elites brasileiras na contenção de qualquer iniciativa de educação popular universalista e a política de desmonte da escola pública levada a cabo no país vizinho no período rosista. Associação indevida, até porque, no Brasil, não havia muito que destruir! Mas, com certeza, a política agressiva de Sarmiento no campo da educação popular antecipou-se em cerca de meio século em relação ao Brasil. Isso equivale a dizer que as elites brasileiras conseguiram retardar por aproximadamente meio século o estabelecimento de uma política de educação popular nacional, dentro dos princípios da escola pública, gratuita e obrigatória, afirmados e perseguidos na Argentina desde a primeira metade da década de 1880! Assim, a partir da Lei Saraiva (1881), grande parte da população brasileira, analfabeta e, agora, excluída do direito de voto, ficou não só afastada da "escola do voto", como dizia José Bonifácio o Moço, mas também espoliada do principal meio de luta pela escola pública! 


\section{Referências}

ARGENTINA. Ley n. 1420. Debate Parlamentario. 2 Tomos. Estúdio preliminar, selectión y notas: Gregorio Weinberg. Buenos Aires: Centro Editor de América Latina, 1984. AZEVEDO, Fernando de. A cultura brasileira. Introdução ao estudo da cultura no Brasil. 4 ed. rev. e ampl. Brasília: Ed. Universidade de Brasília, 1963.

BETHELL, Leslie (Org.). História da América Latina. III - Da Independência até 1870. Trad. Maria Clara Cescato. São Paulo: EdUSP; Imprensa Oficial do Estado; Brasília, DF: Fundação Alexandre Gusmão, 2001.

BETHELL, Leslie. A Independência do Brasil. In: BETHELL, Leslie (Org.). História da América Latina. III - Da Independência até 1870. São Paulo: EdUSP; Imprensa Oficial do Estado; Brasília, DF: Fundação Alexandre Gusmão, 2001. p. 187-230.

BETHELL, Leslie; CARVALHO, José Murilo de. O Brasil da Independência até Meados do Século XIX. In: BETHELL, Leslie (Org.). História da América Latina. III - Da Independência até 1870. São Paulo: EdUSP; Imprensa Oficial do Estado; Brasília, DF: Fundação Alexandre Gusmão, 2001. p. 695-769.

BRADLEY, Ian. The Optimist. Themes and Personalities in Victorian Liberalism. London: Faber and Faber, 1980.

BRASIL. Câmara dos Deputados. Anais. 1878 a 1880. Disponível em: <http://imagem.camara.gov.br/pesquisa_diario_basica.asp >

BRASIL. Lei N. 3.029, 9 janeiro 1881: Lei Saraiva (Reforma da Legislação eleitoral: Sufrágio direto). In: BONAVIDES, Paulo; AMARAL, Roberto. Textos políticos da História do Brasil. Brasília: Senado Federal, 2004. CD-ROM, vol. II - Império, Segundo Reinado (1840-1889).

COSTA, Emília Viotti da. Da Monarquia à República: momentos decisivos. 8 ed. ver. e ampl. São Paulo: Fundação Editora UNESP, 2007.

CUNHA, Euclides da. Diário de uma expedição. Organização de Walnice Nogueira Galvão. São Paulo: Companhia das Letras, 2000. (Coleção Retratos do Brasil)

FAUSTO, Boris. História do Brasil. 11 ed. São Paulo: Ed. Universidade de São Paulo, 2003. FERRARO, Alceu Ravanello. Analfabetismo e níveis de letramento no Brasil: o que dizem os censos? Educação e Sociedade, Campinas, v. 23, n. 81, p. 21-47, dez. 2002.

FERRARO, Alceu Ravanello. Analfabetismo no Brasil: desconceitos e políticas de Exclusão. Perspectiva, Florianópolis, v. 22, n. 1, p. 111-126, jan./jun. 2004.

FREIRE, Paulo. Pedagogia do Oprimido. 6 ed. Rio de Janeiro: Paz e Terra, 1979.

GARANDEAU, Mikaël. Le libéraslisme. Paris: Flamarion, 1998.

GRAHAM, Richard. O Brasil de Meados do Século XIX à Guerra do Paraguai. In: BETHELL, Leslie (Org.). História da América Latina. III - Da Independência até 1870. Tradução de Maria Clara Cescato. São Paulo: EdUSP; Imprensa Oficial do Estado; Brasília, DF: Fundação Alexandre Gusmão, 2001. p. 771-825.

GRIMARÃES, Lucia Maria Paschoal; PRADO, Maria Emília (Orgs.). O liberalismo no Brasil imperial: origens, conceitos e práticas. Rio de Janeiro: Revan: UERJ, 2001.

HOLANDA, Sérgio Buarque de (Dir.). História da civilização Brasileira. II - O Brasil Monárquico. 2 - Dispersão e Unidade. 4 ed. Rio de Janeiro - São Paulo: DIFEL, 1978. HOLANDA, Sérgio Buarque de (Dir.). História da civilização Brasileira. II - O Brasil Monárquico. 3. Reações e Transações. 4 ed. São Paulo: DIFEL, 1982.

HOLANDA, Sérgio Buarque de (Dir.). História da civilização Brasileira. II - O Brasil 
Monárquico. 4 - Declínio e queda do Império. 3 ed. São Paulo: DIFEL, 1982.

HOLANDA, Sérgio Buarque de (Dir.). História da civilização Brasileira. II - O Brasil Monárquico. 5 - Do Império à República. 2 ed. Rio de Janeiro - São Paulo: DIFEL, 1977.

IGLESIAS, Francisco. Vida política, 1848-1868. In: HOLANDA, Sérgio Buarque de (Dir.). História da civilização Brasileira. II - O Brasil Monárquico. 3. Reações e Transações. 4 ed. São Paulo: DIFEL, 1982. p. 9-113.

LOCKE, John. Dois Tratados sobre o Governo. Trad. Júlio Fischer. São Paulo: Martins Fontes, 1998.

LOMBARDI, José Claudinei; SANFELICE, José Luis (Orgs.). Liberalismo e educação em debate. Campinas, SP: Autores Associados, Histedbr, 2007. (Coleção educação contemporânea).

LOSURDO, Domenico. Contra-História do Liberalismo. Trad. Giovanni Semeraro. Aparecida, SP: Idéias \& Letras, 2006.

MACPHERSON, C. B. A teoria política do individualismo possessivo. De Hobbes a Locke. Rio de Janeiro: Paz e Terra, 1979.

MÁRQUEZ, Gabriel García. Cien años de soledad. Ed. Conmemorativa. Texto revisado por el autor para esta edición. Buenos Aires: Editorial Sudamerica, 2007.

MARX, Karl. As lutas de classes em França. Lisboa: Avante!, 1982.

NEVES, Lúcia Maria Bastos P. Liberalismo político no Brasil: idéias, representações e práticas (1920-1923). In: GRIMARÃES, Lucia Maria Paschoal; PRADO, Maria Emília (Orgs.). O liberalismo no Brasil imperial: origens, conceitos e práticas. Rio de Janeiro: Revan: UERJ, 2001. p. 73-101.

SANTOS, Marco Aurélio Martins. Perfis biográficos. Um liberal chamado Sinimbu. In: SENRA, Nelson. História das estatísticas brasileiras. Vol. 1 - Estatísticas desejadas (18221889). Rio de Janeiro: IBGE, 2006. (Obra comemorativa dos 70 anos do IBGE)

SARMIENTO, Domingo Faustino. Facundo: civilização e barbárie no papa argentino. Porto Alegre: Ed. Universidade/UFRGS/EDIPUCRS, 1996. (Coleção Engenho e Arte; 3)

SEAMAN, L.C.B. Victorian England. Aspects of English Imperial History: 1837-1901. London: Mathuen \& Co., 1973.

SENRA, Nelson. História das estatísticas brasileiras. Vol 1 - Estatísticas desejadas (18221889). Rio de Janeiro: IBGE, 2006. (Obra comemorativa dos 70 anos do IBGE).

VARNAGY, Tomás. O pensamento político de John Locke e o surgimento do liberalismo. In: BORON, Atílio A. (Org.). Filosofia politica moderna: de Hobbes a Locke. Buenos Aires: CLACSO; São Paulo: DCP/FFLCH/Universidade de São Paulo, 2006. p. 45-79. WEINBERG, Gregório. Estudo preliminar. In: ARGENTINA. Ley 1420. Debate Parlamentario. 2 Tomos. Buenos Aires: Centro Editor de América Latina, 1984. p. I-XXX. 


\section{Notas}

1 O presente artigo é uma versão resumida, em alguns pontos, do trabalho apresentado no Simpósio "La educación rural en América Latina, Siglos XIX y XX: viejos y nuevos temas", que teve lugar no 53 Congresso Internacional de Americanistas - ICA, na Universidad Iberoamericana, Campus Ciudad de México, de 19 a 24 de julho de 2009, publicado na íntegra nos anais do referido evento.

2 Significa a imposição, nesse ano, de um governo conservador a uma maioria liberal.

3 Segundo o Dicionário Houaiss da Língua Portuguesa, o substantivo "Saquarema" tem os seguintes sentidos: no Brasil: "alcunha que se dava ao partido conservador e a seus membros, na época do Império"; no Rio de Janeiro: "pessoa que vive fora dos centros urbanos; caipira, roceiro, matuto". Como adjetivo, saquarema é "relativo ao partido conservador na época da monarquia e às suas idéias”. No sentido etimológico e topológico, "Saquarema na acepção de partido ou político conservador, prende-se ao fato de que, na época do $2^{\circ}$. Império no Brasil, esta cidade fluminense se tornara célebre como berço de alguns dos mais importantes e representativos políticos de então".

4 No dizer de Emília Viotti da Costa (2007, p. 160), no período da Conciliação, isto é, nos cerca de dez anos que se seguiram a 1852, "as palavras liberal e conservador converteram-se em meras etiquetas".

5 Referindo-se às habilidosas manobras de Disraeli, em 1867, Seaman (1973, p. 162-164) comenta: "Mas [Disraeli] tinha que manter em equilíbrio duas idéias contrárias: uma, que a democracia era perigosa; a outra, que a classe operária olhava para os conservadores como os seus líderes 'naturais". E acrescenta: "É evidente, a simpatia de Disraeli pela classe operária era sempre predominantemente retórica".

6 O autor distingue quatro tipos diferentes de sufrágio então em discussão: a) o sufrágio limitado aos proprietários de bens alodiais (bens imóveis livres de qualquer ônus), no valor de 40 xelins por ano, e aos cidadãos das corporações mercantis: b) o sufrágio para todos os varões chefes de família sujeitos ao fisco para a assistência aos pobres, excluídos os assalariados e pedintes; c) o sufrágio para todos os homens, menos os assalariados e os pedintes; d) o sufrágio para todos os homens, ou todos menos os criminosos e delinquentes. Para o autor, apenas este último tipo se constituía em voto universal (MACPHERSON, 1879, p. 122-127).

7 O acesso foi feito no site http://imagem.camara.gov.br/pesquisa_diario_basica.asp. Não foi possível, ainda, incorporar o levantamento que está sendo feito sobre a tramitação dos dois projetos no Senado do Império. Nas referências dentro do texto, anotar-seá: Câmara, Anais, data da intervenção, página(s) e data do acesso. Tais informações sobre datas e página permitirão localizar facilmente, no referido site, o texto citado.

8 "Para caracterizar el período de Rosas, baste para definirlo el hecho de que constituyó, lisa y llanamente, la negación más completa de los principios que informaron la prédica de un Belgrano o un Rivadavia. Se retaceó el otorgamiento de fondos del erario para el sostenimiento de la enseñanza. [...] Todo esto revela un evidente retroceso [...].” (WEINBERG, 1984, I, p. IV). 
9 Obra clássica de Domingo Faustino Sarmiento sobre o período da ditadura de Rosas, dominado pelos interesses do pampa argentino, em oposição aos interesses urbanos centrados em Buenos Aires.

Recebido: 23/06/2009

Aprovado: 28/10/2009

\section{Contato:}

Universidade Federal do Rio Grande do Sul

Faculdade de Educação

Programa de Pós-Graduação em Educação Av. Paulo Gama s/n

Prédio $12201-7^{\circ}$ andar

Porto Alegre - RS

CEP $90046-900$ 